\title{
Li Zehou's Reconception of the Classical Confucian Concepts of Autonomy and Individuality: With a Focus on Reading the Analects Today
}

JLA Jinbua*

\begin{abstract}
Li Zehou coins the term "guanxi-ism" (relationalism) to confirm the Confucian self with its two aspects of social relations and independent character, while elaborating the classical Confucian notions of individuality, autonomy, and self-realization in his many works, especially in Reading the Analects Today. Li argues that Confucius interprets external ritual as a person' own internal intention and drive, and as a result elevates social and ethical regulations as personal emotions and the autonomous power of decision. With a certain transformative construction, $\mathrm{Li}$ expects that this Confucian project can be efficiently applied in developing humanity and reconstructing the cultural order in today's world.
\end{abstract}

Keywords: Li Zehou, Classical Confucianism, Autonomy, Individuality, Reading the Analects Today

\section{Li Zehoujeva nadgradnja klasičnih konfucijanskih konceptov avtonomije in individualnosti v delu Današnje branje Razprav}

\section{Izvleček}

Medtem ko je v mnogih svojih delih, zlasti v knjigi Današnje branje Razprav, nadgrajeval konfucijanske koncepte individualnosti, avtonomije in samouresničevanja, je Li Zehou uvedel termin "guanxi-ism" (relacionalizem) za ponazoritev konfucijanskega sebstva, ki vsebuje dva vidika, namreč vidik družbenih odnosov in vidik samostojnega značaja. Li trdi, da je Konfucij interpretiral zunanjo obrednost kot notranjo namero in motivacijo posameznika, iz česar sledi, da je družbene in etične regulacije povzdignil na raven osebnih čustev in avtonomne moči odločanja. Li pričakuje, da bo tak projekt konfucijanske prenove $-\mathrm{z}$ določeno mero transformacijskih konstrukcij - lahko učinkovito uporabljen $\mathrm{v}$ razvoju in rekonstrukciji kulturnega reda današnjega sveta.

Ključne besede: Li Zehou, klasično konfucijanstvo, avtonomija, individualnost, Današnje branje Razprav

JIA Jinhua, Chair Professor of Yangzhou University, China, and Professor of The Hong Kong Polytechnic University, Hong Kong. Email address: jennifer2new@yahoo.com

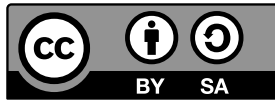




\section{Introduction}

Li Zehou was among the early scholars to notice the classical Confucian concepts of autonomy and individuality. He coins the term “guanxi-ism” 關係主義 (relationalism), promoting it as a reconception of classical Confucian ethics encompassing both human relationality and individuality, as well as social role obligations and personal autonomy. $\mathrm{Li}$ asserts that the core theme of the Analects is “learning to become a person" (xue zuoren 學做人; Li 2015, 192-93), in which a consummate person has come to realize both social responsibility and individual worth. In the preface to his Lunyu jindu 論語今讀 (Reading the Analects Today), Li summarizes three basic ideas of this classic: (1) a particular emphasis on the nurturing of human emotions, regarding emotion as the foundation, substance, and source of humanity and life; (2) an extreme emphasis on morality, integrating politics, ethics, and religion into one; and (3) a self-establishment of individuality and destiny in order to realize one's personal worth of existence (Li 1998, 18-21). Among the three, the first and the third concern the notions of individuality, personal psychology, autonomy, and self-realization.

During the nineteenth and twentieth centuries, a dominant opinion of scholarship was that Confucian ethics lacked the notions of self, individuality, subjectivity, autonomy, and free will. For example, Hu Shi 胡適 asserted that in Confucian ethics a person cannot exist independently, but is always subject to social relations (Hu 1919, 116). Liang Shuming 梁漱溟 also contended that Chinese society is relation-based (guanxi benwei 關係本位) and that "the biggest problem of Chinese culture is that the individual has never been discovered" (Liang 1974, 94, 260). Likewise, Herbert Fingarette opposed using the concept of self to discuss Confucian thought because Confucian ethics lacks the language of choice, responsibility, and subjectivity (Fingarette 1998, 18-36; 1979, 129-40. See also Hegel 1956, 120-21; Weber 1951, 241; Hansen 1972, 169-86; 1985, 35-56).

In recent decades, although a number of scholars have now confirmed the Confucian notion of self they still define it as being constituted mainly by relational roles, social responsibility, and communal values, rather than as describing a basically free, autonomous individual. For example, to A. C. Graham, although Confucius is very much concerned with individual choice, he "does not think in terms of choices between ends" but of simply spontaneously following the Dao as his intent and learning progresses, rather than the free choice of the individual will (Graham 1989, 27-28). Henry Rosemont, Jr. also believes that "Confucian selves are much less autonomous individuals than they are relational persons, persons leading lives integrated morally, aesthetically, politically, and spiritually; and they lead these lives in a human community" (Rosemont 2004, 62-63; 2015. See also Sun 2011; Ames 1991, 103-14). 
Meanwhile, some scholars have found that Confucian ethics in fact advocates an organic relationship between the individual and society, and consider the two as interdependent and inseparable. For example, in Ambrose Y. C. King's opinion, Confucianism sees the individual as "a relational being endowed with a self-centered autonomy," with considerable social and psychological space for action and capable of shaping what kinds of relationships to have with others (King 1985, 57-70; 1992, 1-40). Yu Ying-shih 余英時 also indicates that Confucian ethics treats the individual as a whole being of reason, emotion, will, and desire; neither is the relational order forced on the individual from outside but rather it spontaneously emerges from within the individual (Yu 1989, 1-48). Heiner Roetz describes the Confucian moral person as a self-responsible, autonomous being who does more than simply fulfil assigned social roles and obligations (Roetz 1993, 149-84). Additionally, since the beginning of the twenty-first century, more and more scholars have applied the notions of self, autonomy, freedom, and individuality in a general sense for discussions of their presentation in Confucian ethics (see mainly Perkins 2002, 207-26; Shun 2004; Cheng 2004, 124-47; Brindley 2010; Chan 2014).

Against this background of scholarship, Li Zehou's plentiful, sophisticated discussion of classical Confucian notions concerning emotion, autonomy, individuality, and self-realization in his Reading the Analects Today, published in 1998 and absorbed from his many ideas presented in his works from the late 1970s to 1990s (Li 1979a; 1979b; 1981a; 1981b; 1985; 1987; 1989), appears both pioneering and inspiring in this regard. It therefore merits a detailed discussion.

\section{Personal Emotions and Autonomous Decisions}

Herbert Fingarette emphasized the importance of $l i$ 禮 or ritual regulations while asserting the lack of an individual power of decision and "inner psychic life" in classical Confucian ethics: "The moral task is to make a proper classification, to locate an act within the scheme of $l i$.... In short, the task is posed in terms of knowledge rather than choice." Here "proper classification" refers to the "ordering of names" (zhengming 正名), which is related to the "knowledge" of ritual regulations. Although Fingarette admits that Confucius talks about a kind of self that is "self-observing and self-regulating", he describes it as representing the impersonal Dao without any true subjective state (Fingarette 1998, 18-36; 1979, 45).

Li Zehou shares Fingarette's emphasis on the relationship between ritual and classical Confucian ethics; indeed, to a certain extent Li's discussion on the magic and ethical power of ritual regulations (customs, institutions, social order, and laws) develops Fingarette's viewpoint ( $\mathrm{Li} 2015)$. On the other hand, $\mathrm{Li}$ also pays close attention to the Confucian self of emotions, subjectivity, and autonomy, 
indicating that one of Confucius' most important contributions is to root external ritual regulations in the internal psychology of ren 仁, which basically means to love people, or humaneness ( $\mathrm{Li}$ 1985, 15-33; Jia 2016, 757-86). The integration of $l i /$ ritual and $r e n /$ humaneness in one's inner psychology thus forms what Li calls the emotio-rational formation (qing-li jiegou 情理結構) of classical Confucianism. As a result:

By obtaining this internal psychological grounding, ritual regulations become part of humanity. ... The standards and commands given by the divine shift into internal human drives and consciousness, and service to the divine shifts into service to humans and to self. This transformation possesses epochal significance in the history of ancient Chinese thought.

\section{禮由于取得這種心理學的內在依據而人性化，...由神的準繩命令變 而爲人的內在欲求和自覺意識，由服從于神變而爲服從于人，服從 于自己, 這一轉變在中國上古思想史上具有劃時代的意義. (Li 2015, 118-19; Li 2018c)}

The divine authority and ritual regulations thus become the inner emotion, drive, and consciousness of the individual. These are no longer forced from external orders but arise from the internal will. The individual is changed from following Heaven/the gods to following his or her own intention. As a result, individual decisions, choices, and autonomous actions are required for implementing the practices of ritual.

Li Zehou takes Confucius' conversation about the ritual of mourning with his disciple $\mathrm{Zai} \mathrm{Yu}$ 宰予 as an important example of this. Zai Yu disagrees with the ritual of three years' mourning, claiming that a full year is long enough. Confucius asks if he is at ease with one year of mourning and Zai Yu replies yes. Confucius then tells Zai Yu that "if you feel at ease, do so by all means", while at the same time reprimanding him as “inhumane" (buren 不仁) because “a child ceases to be nursed by his parents only when he is three years old. ... Was Zai Yu not given three years'love by his parents?"1 (17.21; Lau, 1979). Li Zehou contends that Confucius directly explains the ritual of three years' mourning as an emotional and rational self-awareness that repays the parents' unconditional love for their children, as well as displaying the children's sincere love for their parents. Here the key word is an 安, or at ease, which refers to personal emotions and feelings but is also established on rational knowledge, as seen in the reciprocal care between parent and child. Confucius thus interprets the external ritual regulations as the individual's internal intentions; elevates the rigid, coercive regulations to the individual's conscious

1 Translations of the Analects in this article are adapted from D. C. Lau's. 
concepts and autonomous decisions; and changes the religious, mysterious rituals into the individual's daily emotions and life experience. In this way, ethical regulations and psychological intentions are unified, and rituals are humanized because they have acquired psychological grounding ( $\operatorname{Li} 1985,18-22 ; 1998,407-8)$.

Likewise, when interpreting Confucius' famous phrase, "to return to ritual regulations through mastering oneself, this is humaneness" (12.1), Li Zehou indicates that ren or humaneness is neither natural human desire nor a "Heavenly principle" (tianli 天理) that overcomes or extinguishes human desire; rather, it is the mastering of oneself to make one's words and acts conform to $\mathrm{li} /$ the ritual regulations that produce ren or the emotion of humanity. It is both humankind's historical achievement and the individual's psychological formation, and both a cultural-regulating scheme (human culture) and individual autonomous drive (humanity). As a result:

Confucius transfers the practice of an external ritual institution into an internal drive and intention, and integrates reason and drive to become the specific process of emotion (humanity, i.e. ren).

孔子將實踐外在禮制化爲內心欲求，融理欲于一體而成爲情（人 性，即仁）的具體過程. (Li 1998, 270)

The same integration of reason, drive, emotion, and will by the individual self, $\mathrm{Li}$ further indicates, is also present in Confucius' many other teachings; for instance, “Enacting humaneness occurs through oneself” 為仁由己 (12.1); “I desire to be humane, and humaneness arrives” 我欲仁, 斯仁至矣 (7.30); “A determined humane person does not seek to preserve one's life at the expense of damaging humaneness, but rather sacrifices one's life to achieve humaneness” 志士仁人, 無求 生以害仁, 有殺身以成仁 (15.9); and “The Three Armies can be deprived of their commander, but even a common man cannot be deprived of his will” 三軍可奪帥 也, 匹夫不可奪志也 (9.26; Li 2015, 194-98). In these expressions, Confucius ascribes to the individual the capacity of acting autonomously under the individual's own drive, will, and moral principles, independent of consequential considerations or external controls and forces.

In Reading the Analects Today, Li Zehou mainly uses the terms "individual freedom” (getiziyou 個體自由), “individual autonomy” (geti zizhu 個體自主), or “psychological freedom" (xinli ziyou 心理自由) to signify the exercise of individual autonomy. In other works, and especially in recent years, Li has also used the term “free will" (yizbi ziyou 意志自由) for this signification. He explains that his use of free will is related to Kant's definition but has also been revised on classical Confucian grounds. 
Kant describes the will both as practical reason that fulfils an end and as a faculty that produces rational action (Korsgaard 1996, 163; Li 2018a, 230-35). Like Kant, Li Zehou also emphasizes that the Confucian notion of free will is characterized by the governance of reason:

I have repeatedly mentioned that the emotio-rational formation of moral psychology is characterized by the governance of reason. This can be seen where Confucius describes the great virtue of "humaneness" as "mastering oneself and returning to ritual regulation", which involves the categorical imperative of reason. Therefore, in terms of the psychological character of morality, Confucius and Kant are entirely in line with one another on this major point.

道德心理的情理結構我已反復講了, 就是以理性主宰爲特徵, “克己 復禮爲仁”，克己復禮就是理性的絕對命令. 因此作爲道德的心理特 徵, 孔老夫子與 Kant 在這一要點上完全一致. (Li 2015, 195)

Within the emotio-rational structure of moral psychology, reason governs individual emotions and desires through the exercise of free will. Confucius explains "mastering oneself and returning to ritual regulation" as ren/humaneness, which emphasizes the self-coercion of Kant's categorical imperative.

On the other hand, Kant's notion of free will is related to his epistemology that separates intelligence and reason from sensibility and emotion, a priori moral principles from historical, empirical factors of human psychology, and the noumenal from the phenomenal. He distinguishes the intelligible character of freedom from its empirical character, the former being the spontaneity of understanding and autonomy of the will, the latter being the receptivity of the sensibility and heteronomy of the will. In other words, we can gain full free will only in the "noumenal" world, not in the phenomenal one (Wood 1984, 73-101; Li 2018a, 230-34). In contrast, however, Li Zehou stresses the importance of emotion and how it is integral to reason in the Confucian notion of free will, thus differing from Kant:

Confucius also famously states, "Humaneness is to love people". This statement clearly emphasizes emotions. Likewise, while "mastering oneself and returning to ritual propriety" stresses rationality, the totality of Confucius' teachings regarding "humaneness" ultimately focuses on the formation of humanity's emotio-rational structure, within which both emotion and rationality are integral. This differs from Kant's exclusive focus on the supremacy of reason. Kant's reason is above and beyond 
humankind, whereas Confucius' "emotio-rational formation" belongs only to humankind. This is their fundamental difference.

孔子還有 “仁者愛人” 的著名回答, 這個回答所突出的, 確是情感, 有 如 “克己復禮” 的回答側重理性. 但總括孔子對 “仁” 的衆多回答, 其 最終歸結仍在塑建既有情又有理的人性的情理結構，而不同于Kant 只講理性至上. Kant的理性是超于和高于人類的, 孔夫子的 “情理結 構”是專屬人類的. 這就是根本的不同. (Li 2015, 195-96)

Therefore, the free will of the Chinese tradition is full of emotion and content, unlike Kant's free will of universal legislation but without content, as criticized by Hegel.

所以中國傳統的自由意志充滿情感和內容, 而不同于爲Hegel所批評 的康德那雖普遍立法却無內容的自由意志 (Li 2018b, 14).

"Free will" lies not in a Heavenly principle, but rather in the human heart-mind.

这自由意志不在天理, 而在人心. (Li 2011, 5).

Thus, first, the Confucian free will is filled with moral emotion, with the core notion of $\mathrm{ren} /$ humaneness stressing the emotion of loving people. Second, ren/ humaneness also integrates emotion with reason to form one's individual moral psychology. Third, the Confucian religio-rational formation is historically and culturally relative, exclusively belonging to human experience. Therefore, in contrast to the Kantian universal legislative of "formal" free will, the Confucian free will is emotional, rational, substantive, and personal. For example, Li Zehou elaborates the description of "[Confucius] keeps working towards his goal while knowing it is hopeless to success” 知其不可而爲之 in the Analects (14.38) as follows:

"Knowing it is hopeless to success" is an understanding [of the reality], while "still working towards one's goal" is to make efforts without calculating the result of success or failure, showing the understanding of ethical "noumenon" higher than phenomenal world and the dignity of human without submitting to causality. 
“知其不可” 是認識, “而為之” 則是偏偏不計較成敗因果而去做, 正顯 示倫理“本體”高于現象界的認識, 顯示了人的尊嚴, 不屈從于因果的

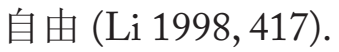

The individual rationally estimates the reality of arduous circumstances in their life journey but still makes great efforts to overcome difficulties, thus showing their free will of not yielding to Heaven's mandate.

From Li Zehou's discussion of the relationship between li/ritual regulations and ren/humaneness, we can draw three key arguments of his. First, Li argues that Confucius internalizes external ritual regulations to within the individual to become humaneness, as a result providing the grounding of the individual's "inner psychic life" for implementing the moral tasks of the ritual regulations and relational social order. Second, according to Li, in the Analects ren is a kind of moral-rational emotion of loving people, representing fundamental humanity; it is universal but also personal at the same time, because it starts with people's specific feelings of love toward their parents as well as their rational drive to repay them. Finally, Li contends that the individual makes the autonomous decision to practice ren or not and to become a humane person or not based on their own emotions, drives, reasons, and free will. In the example of three years' mourning, Zai Yu feels "at ease" about not implementing the ritual and so chooses to be "inhumane", while Confucius determines on the opposite decision. These arguments thus insightfully reveal some fundamental conceptions of classical Confucianism with regard to the ethical categories of morality, humanity, emotion, reason, and individual autonomy.

In several other passages of the Analects, Li Zehou again looks into the depth and detail of Confucius' words to reveal the implied concept of personal independency, particularity, and autonomy. For example:

The master says, “... A man good enough as a partner in a common stand need not be good enough as a partner in the exercise of flexibility”.

子曰: “...可與立，未可與權”(9.30).

As is well-known, “jing” 經 and “quan” 權 are paired concepts in Chinese intellectual history. Li Zehou explains jing as principle and quan as flexibility, contending that $j i n g /$ principle is a universal law that cannot be changed, while quan/flexibility is related to individuality and personal autonomy, and thus the ability to undertake free and flexible decisions and practices. Classical Confucianism does not emphasize absolute imperatives and principles that never change, but instead stresses the integration of constancy and change, and principle and flexibility. Furthermore, Confucius says he differs from a number of virtuous hermits and officials because 
he has "no preconceptions about the permissible and the impermissible" (wuke wu buke 無可無不可; 18.8). Li comments that this also displays Confucius' flexibility and particularity in making his own personal decisions and choices. Some additional examples from the Analects are as follows:

The master says, "The gentleman agrees with others without being an echo. The small man echoes without being in agreement”.

子曰: “君子和而不同, 小人同而不和”(13.23).

The master says, "The gentleman is conscious of his own superiority without being contentious, and comes together with other gentlemen without forming cliques."

子曰: “君子矜而不爭, 群而不黨”(15.22).

The master says, "The gentleman enters into associations but not cliques; the small man enters into cliques but not associations."

子曰: “君子周而不比, 小人比而不周”(2.14).

For the three expressions concerning a gentleman's right acts- "agrees with others without being an echo", "comes together with other gentlemen without forming cliques", and "enters into associations but not cliques"- $\mathrm{Li}$ explains these as Confucius' emphasis on cultivating individual particularity and independency in order to maintain social and relational harmony.

\section{The Ideal Personality and Self-Realization}

In the early 1980s, Li Zehou had already listed “individual personality" (geti renge 個體人格) as one of the five components of Confucius' conception of $\mathrm{ren} / \mathrm{hu}$ maneness (Li 1980, 87-89; 1985, 25-29). Later, he further defined the Confucian program of constructing the ideal personality through self-cultivation as the practice of the “inner sage" (neisheng 內聖) or "religious morality" (zongjiaoxing daode 宗教性道德), in contrast with the practice of the “outer king” (waiwang 外王) or “social morality” (shehuixing daode 社會性道德). Li also reinterprets Confucius' "knowing Heaven's mandate" (zhiming 知命) and Mencius' "standing on Heaven's mandate” (liming 立命) as overcoming one's individual destiny and self-realization of personal worth. 
Li Zehou argues that when Confucius roots external ritual regulations in the internal psychology of humaneness during the late Spring and Autumn periods, when the Zhou ritual starts to collapse, he is in fact entrusting the historical mission of restoring the institution of ritual to members of the aristocracy. To fulfil this mission, a junzi 君子 (literally “lord's son") must learn and cultivate himself to attain the ideal personality of humaneness. As Confucius says:

A humane person helps others to take their stand if he himself wishes to take the stand, and helps others to accomplish if he himself wishes to accomplish.

夫仁者已欲立而立人, 已欲達而達人 (6.30).

Or as Zengzi says:

A gentleman must be strong and resolute, for his burden is heavy and the road is long. He takes humaneness as his burden. Is that not heavy? Only with death does the road come to an end. Is that not long?

士不可不弘毅, 任重而道遠. 仁以爲已任, 不亦重乎? 死而後已, 不亦 遠乎? (8.7)

Humaneness is thus both a social obligation and an autonomous choice, both the ideal personality and an individual act. It is to love and help others unconditionally, and at the same time complete the nurturing of one's individual personality and realize one's individual worth. As a result, both the individual and group reach perfection and elevation. Li Zehou contends that the personality of humaneness established by Confucius replaces the image of the religious saint while possessing the same strength and function, which in turn greatly promotes personal autonomy and independency. Following this ideal model, later Confucians always emphasized self-cultivation, or the "inner sage", as the foundation of governing the state, or the "outer king". Indeed, numerous Confucian scholars have practiced self-cultivation and pursued becoming a consummate person throughout their lives. This is the religious morality of Confucianism, which functions quasi-religiously in order to remove secular dirt from determined scholars. Here again we see that in Confucian ethics, social, relational persons are also dynamic individuals who actively construct their own and others' roles and personalities. This construction is not simply an action of following the Dao, but rather requires great strength in individual will, determination, and practice. 
Confucius himself sets up an example for such self-cultivation of the ideal personhood. His famous self-reflection on life's stages describes the progressive process of his pursuing and becoming a consummate person (2.4). Among these stages, the central point is knowing Heaven's mandate at age fifty. Before this point, all his efforts in learning and practicing were making gradual progress toward this knowledge; after this point, all his free yet rational feelings and ideas were the outcomes of this knowledge. As for the implications of "knowing Heaven's mandate", both traditional and modern scholars have developed numerous interpretations, and controversies over whether it concerns a moral Heaven or amoral fate, and prescriptive/normative or descriptive dimensions, have continued (see mainly Ruan 1982, 1: 211-36; Feng 1948, 44-47; Fu 2000, 2: 499-666; Tang 1957,1-33; Miyazaki 1963, 81-104; Xu 1969; Mori 1971; Schwartz 1985, 117-27, 285-90; Hall and Ames 1987, 206-7; Eno 1990, 249-50; Slingerland 1996, 567-81; Shun 2000, 77-88; N. Chen 1997a, 495-520; 1997b, 323-59).

For his part, Li Zehou has offered his own interpretation of Confucius' "knowing Heaven's mandate" together with Mencius' "standing on Heaven's mandate". He explains "Heaven's mandate" as personal destiny, which is determined by contingency (ouranxing 偶然性) beyond human knowledge and imagination, and argues that "knowing Heaven's mandate" refers to a person's power to decide and control his/her own destiny:

Knowing and revering Heaven's mandate should not be explained as an external imperative or government. It should be understood as cautiously and reverently bearing all external contingencies, "without complaining to Heaven and people". Going through various difficulties and hazards in one's life journey, one establishes one's own necessity without the cost of autonomy. In this way, one is conscious of one's finitude but is at the same time using it to resist, commit, and establish. This is standing on destiny, correct destiny, and knowing Heaven's mandate. "At fifty I knew Heaven's mandate" means the completion of this kind of commitment and establishment, that is, one thoroughly controls one's destiny.

知天命畏天命便不釋爲外在的律令或主宰, 而可理解爲謹慎敬畏地 承擔起一切外在的偶然, “不怨天不尤人”, 在經歷各種艱難險阻 的生活行程中，建立起自己不失其主宰的必然. 亦既認同一己的有 限，却以此有限來抗阻，來承擔，來建立，這也就是立命，正命和 知天命. “五十而知天命” 著意在這種承擔和建立的完成，即一己 對命運的徹底把握. (Li 1998, 53) 
Although views may differ about explaining destiny as contingency, Li's interpretation of "knowing Heaven's mandate" as a person's power and effort to decide and control his or her own destiny is insightful. Li argues that in Confucius'statement, to revere and know Heaven's mandate/personal destiny is not to submit and yield to it. Rather, it is a deep consciousness of one's own existence and its limits, finitude, and difficulty; from the basis of this consciousness one cherishes the worth, meaning, and mission of one's life and strives to realize it so that eventually one controls one's own destiny, as Mencius' notion of "standing on/establishing Heaven's mandate" expresses more clearly. Therefore, the Confucian view of Heaven's mandate is two-sided: on the one hand revering the unpredictable future and one's destiny, and on the other believing in one's own strength, effort, and capacity to exert significant control over that destiny. This two-sided view has long been the common understanding and practice of the Chinese people, as vividly presented in well-known sayings such as "Doing one's utmost while listening to Heaven's mandate" (Jin renshi er ting tianming 尽人事而听天命), “Knowing it is hopeless to succeed but still working toward one's goal” (Zhi qi buke er weizhi 知其不可而為之), and “The efforts lies with man while the outcome lies with Heaven" (Moushi zairen, chengshi zaitian 謀事 在人, 成事在天; Li 1998, 277).

Li Zehou's argument can be further elaborated. The Qing scholar Sun Qifeng 孫奇逢 (1584-1675) insightfully indicated that Confucius' knowing Heaven's mandate was in fact Confucius' knowing himself (Yang 1985, 22). Through decades of diligently learning, cultivating, and practicing, at age fifty Confucius knew clearly his own disposition, intelligence, abilities, knowledge, moral virtue, social roles and obligations, and, most importantly, the socio-historical mission he had chosen to undertake. This notion of self-knowing was later correctly seized on by the author(s) of the Guodian 郭店 manuscript Zun deyi 尊德義 in saying: "There are those who know themselves but don't know [Heaven's] mandate, whereas there is never someone who knows [Heaven's] mandate but does not know himself” 有知已而不知命者, 亡知命而不知已者 (Chen W. 2009, 213).

Heaven's mandate represents the cosmic authority; knowing and following Heaven's mandate means to conform to external authority. The significance of Confucius knowing Heaven's mandate lies in that, by changing the subject to be known from Heaven to himself, the cosmic authority is transferred to become the internal, individual authority that motivates one to choose, determine, and act. Thus, under the surface of Heaven's mandate lies a self-empowering and self-realizing agent who determines his own course of life. 


\section{Concluding Remarks}

Classical Confucian ethics emphasizes both ritual/ethical regulations and personal emotion and power of decision, as well as both social/relational obligations and individual autonomy and realization. During the 1980s and 1990s, while most scholars focused on the social values of Confucian ethics, Li Zehou confirmed the Confucian self with its two aspects of social relations and independent character, while elaborating the classical Confucian notions of individuality, autonomy, and self-realization in his many works, especially in Reading the Analects Today. Li argues that Confucius interprets external ritual as a person' own internal intention and drive, and as a result elevates social and ethical regulations as personal emotions and the autonomous power of decision. Ren/ humaneness, the core notion of Confucian ethics, is an emotio-rational formation of humanity, which is both governed by the rationality of ethical obligation and integrated with individual emotion, and the ideal personality of loving and helping other people. Through self-cultivation and practice, individuals can control their own destiny and realize their own personal worth by contributing to social and historical progress.

In addition to the term guanxi-ism, denoting both meanings of human relationality and individuality, as mentioned at this article's beginning, Li Zehou has also coined other novel, paired terms, such as emotio-rational formation, religious morality and social morality, ethics and morality, and subjectality (zhutixing 主 體性) and subjectivity (zhuguanxing 主觀性; Li 1999, 174-83). In doing so he has reconceptualized the Confucian project of cultivating the ideal personality through integrating social values with individual worth, ethical regulations with autonomy, and relational obligations with personal realization.

With a certain transformative construction, Li expects, this Confucian project can be efficiently applied in developing humanity and reconstructing the cultural order in today's world. On the one hand, it stresses each person's emotions, autonomous decisions, free development, and self-realization; on the other, it revises modern liberalism's over-projection of the "atomic individual" and absolute freedom while ignoring social and community interests. Externally it can inspire us to build social harmony and interpersonal care based on individual rights and interests; internally it can guide us to foster personal emotions, character, and humanity (Li 2014,105-7, 113-17). In the end, "everything, including ethics and morality, eventually completes in the individual”一切包括倫理道德 最終歸結于個體 (Li 2017, 379), who can thus become fully human through the Confucian project of "person making" (Hall and Ames 1987, 114-25). 
References

Ames, Roger T. 1991. "Reflections on the Confucian Self: A Response to Fingarette." In Rules, Rituals, and Responsibility: Essays Dedicated to Herbert Fingarette, edited by Mary I. Bockover, 103-14. Chicago: Open Court.

Bockover, Mary I., ed. 1991. Rules, Rituals, and Responsibility: Essays Dedicated to Herbert Fingarette. Chicago: Open Court.

Brindley, Erica F. 2010. Individualism in Early China: Human Agency and the Self in Thought and Politics. Honolulu: University of Hawai'i Press.

Chan, Joseph. 2014. Confucian Perfectionism: A Political Philosophy for Modern Times. Princeton and Oxford: Princeton University Press.

Chen, Ning. 1997a. "The Concept of Fate in Mencius." Philosophy of East and West 47 (4): 495-520.

_. 1997b. "Confucius' View of Fate (Ming)." Journal of Chinese Philosophy 24 (3): 323-59.

Chen, Wei 陳偉 et al., eds. 2009. Chudi chutu Zhanguo jiance [shisi zhong] 楚地出 土戰國簡冊 (十四種) (Fourteen Bamboo Manuscripts Excavated from the Chu State of Warring States). Beijing: Jingji kexue chubanshe.

Cheng, Chung-ying. 2004. "A Theory of Confucian Selfhood: Self-Cultivation and Free Will in Confucian Philosophy." In Confucian Ethics: A Comperative Study of Self, Autonomy, and Community, edited by Kwong-loi Shun and David B. Wong, 124-47. Cambridge: Cambridge Unicersity Press.

Eno, Robert. 1990. The Confucian Creation of Heaven Philosophy and the Defense of Ritual Mastery. Albany: State University of New York Press.

Feng, Youlan 馮友蘭. 1948. A Short History of Chinese Philosophy. Translated and edited by Derk Bodde. New York: Free Press.

$\mathrm{Fu}$, Sinian 傅斯年. 2000. “Xingming guxun bianzheng 性命古訓辨證 (Examination of Ancient Interpretations on Xing and Ming)." In Fu Sinian quanji 傅 斯年全集 (Collected Works of Fu Sinian), vol. 2: 499-666. Changsha: Hunan jiaoyu chubanshe.

Fingarette, Herbert. 1979. "The Problem of the Self in the Analects." Philosophy of East and West 29 (2): 129-40.

-1998. Confucius: The Secular as Sacred. Long Grove, IL: Waveland Press. Graham, A. C. 1989. Disputers of the Tao. La Salle, IL: Open Court.

Hall, David, and Roger T. Ames. 1987. Thinking through Confucius. Albany: State University of New York Press.

Hansen, Chad. 1972. "Freedom and Moral Responsibility in Confucian Ethics." Philosophy East and West 22 (2): 169-86.

- 1985. "Individualism in Chinese Thought." In Individualism and Holism: Studies in Confucian and Taoist Values, edited by Donald J. Munro, 35-56. Ann Arbor: University of Michigan Press. 
Hegel, Georg Wilhelm Friedrich. 1956. The Philosophy of History. Translated by J. Sibree. New York: Dover.

$\mathrm{Hu}$, Shi 胡適. 1919. Zhongguo zhexueshi dagang 中國哲學史大綱 (Outline of Chinese Philosophy History). Beijing: Shangwu yinshuguan.

Jia, Jinhua. 2016. "Li Zehou's Reconception of Confucian Ethics of Emotion." Philosophy East and West 66 (3): 757-86.

King, Ambrose Y. C. 金耀基. 1985. “The Individual and Group in Confucianism.” In Individualism and Holism: Studies in Confucian and Taoist Values, edited by Donald J. Munro, 57-70. Ann Arbor: University of Michigan Press.

- 1992. Zhongguo shehui yu wenhua 中國社會與文化 (Chinese Society and Culture). Hong Kong: Oxford University Press.

Korsgaard, Christine M. 1996. Kant's Moral Philosophy. New York: Cambridge University Press.

Lau, D. C., trans. 1979. The Analects. London: Penguin Books.

Li, Zehou 李澤厚. 1979a. Pipan zhexue de pipan: Kangde shuping 批判哲學的批 判: 康德述評 (A New Approach to Kant: Critique of the Critical Philosophy). Beijing: Renmin chubanshe.

-1979b. Zhongguo jindai sixiang shilun 中國近代思想史論 (On the History of Early Modern Chinese Thought). Beijing: Renmin chubanshe.

—. 1980. “Kongzi zai pingjia 孔子再評價 (Reevaluation of Confucius).” Zhongguo shehui kexue 中國社會科學 (Chinese Social Science) 2: 87-89.

-1981a. Meixue lunji 美學論集 (Essays on Aethetics). Shanghai: Shanghai wenyi chubanshe.

- 1981b. Mei de licheng 美的歷程 (The Path of Beauty). Beijing: Wenwu chubanshe.

1985. Zhongguo gudai sixiang shilun 中國古代思想史論 (On the History of Ancient Chinese Thought). Beijing: Renmin chubanshe.

. 1987. Zhongguo xiandai sixiang shilun 中國現代思想史論 (On the History of Modern Chinese Thought). Beijing: Dongfang chubanshe.

—.1989. Meixue si jiang 美學四講 (Four Essays on Aesthetics). Beijing: Sanlian shudian.

—. 1998. Lunyu jindu 論語今讀 (Reading the Analects Today). Hong Kong: Tiandi tushu gongsi.

.1999. “Subjectivity' and 'Subjectality': A Response." Philosophy East and West 49 (2): 174-83.

- 2011. Lunlixue gangyao 倫理學綱要 (Outline of Ethics). Beijing: Peking University Press.

.2014. Huiying Sangde'er ji qita 回應桑德爾及其他 (A Response to Michael Sandel and Other Matters). Beijing: Sanlian shudian.

2015. You wu dao li shi li gui ren 由巫到禮釋禮歸仁 (From Shamanism to Ritual Regulations and Humaneness). Beijing: SDX Joint Publishing Company. 
.2017. Lunlixue gangyao xupian 倫理學綱要續篇 (Sequel to Ouline of Ethics). Beijing: Sanlian shudian.

- 2018a. A New Approach to Kant: A Confucian-Marxist's Viewpoint. Singapore: Springer Nature.

. 2018b. “Guanyu 'Lunlixue zonglangiao' de shuoming (2018) 關于 ‘倫理 學總覽表” 的說明 (Explanation to 'A General Table of Ethics').” Zhongguo wenhua 中國文化 (Chinese Culture) 1:1-15.

2018c. The Origins of Chinese Thought: From Shamanism to Ritual Regulations and Humaneness. Translated by Robert A. Carleo III. Leiden: Brill.

Liang, Shuming 梁漱溟. 1974. Zhongguo wenhua yaoyi 中國文化要義 (Essentials of Chinese Culture). Taibei: Zhongzheng shuju.

Miyazaki, Ichisada 宮崎市定. 1963. “Chūgoku kodai ni okeru ten to mei to tenmei no shisō 中國古代における天と命と天命思想 (Tian, Ming and Heaven’s Mandate in Ancient China)." Shirin 史林 (Historical Studies) 46 (1): 81-104.

Mori, Mikisaburô 森三樹三郎. 1971. Joko yori Kandai ni itaru seimeikan no tenkai:jinseiron to unmeikan no rekishi 上古より漢代に至る性命觀の展開: 人生 論と運命観の歴史 (Development of the Concept of Xing and Ming from Ancient to Han Dynasty: A History of Outlook on Life and Destiny). Tokyo: Sobunsha.

Munro, Donald J., ed. 1985. Individualism and Holism: Studies in Confucian and Taoist Values. Ann Arbor: University of Michigan.

Perkins, Franklin. 2002. "Mencius, Emotion, and Autonomy." Journal of Chinese Philosophy 29 (2): 207-26.

Roetz, Heiner. 1993. Confucian Ethics of the Axial Age. Albany, N.Y.: State University of New York Press.

Rosemont, Henry Jr. 2004. "Whose Democracy? Which Rights? A Confucian Critique of Modern Western Liberalism." In Confucian Ethics: A Comperative Study of Self, Autonomy, and Community, edited by Kwong-loi Shun and David B. Wong, 49-71. Cambridge: Cambridge Unicersity Press.

-2015. Against Individualism: A Confucian Rethinking of the Foundations of Morality, Politics, Family, and Religion. New York: Lexington Books.

Ruan, Yuan 阮元. 1982. “Xingming guxun 性命古訓 (Ancient Interpretations on Xing and Ming).” Yanjingshi ji 揅經室集 (Collection of Scripture Studio) 1: 211-36. Taibei: Shijie shuju.

Schwartz, Benjamin. 1985. The World of Thought in Ancient China. Cambridge, MA: Harvard University Press.

Shun, Kwong-loi. 2000. Mencius and Early Chinese Thought. Stanford, Calif.: Stanford University Press.

2004. "Conception of the Person in Early Confucian Thought." In Confucian Ethics: A Comperative Study of Self, Autonomy, and Community, edited by Kwong-loi Shun and David B. Wong, 183-99. Cambridge: Cambridge Unicersity Press. 
Shun, Kwong-loi, and David B. Wong, eds. 2004. Confucian Ethics: A Comparative Study of Self, Autonomy, and Community. Cambridge: Cambridge University Press.

Slingerland, Ted. 1996. "The Conception of Ming in Early Confucian Thought." Philosophy of East and West 46 (4): 567-81.

Sun, Longji 孫隆基. 2011. Zhongguo wenhua de shenceng jiegou 中國文化的深層 結構 (The Deep Structure of Chinese Culture). Guilin: Guangxi shifan daxue chubanshe.

Tang,Junyi 唐君毅.1957. “Xianqin sixiang zhong zhi tianming guan 先秦思想中 之天命觀 (The Concept of Heaven's Mandate in Pre-Qin Thought).” Xinya xuebuo 新亞學報 (New Asia Journal) 2 (2): 1-33.

Weber, Max. 1951. The Religion of China. Translated by Hans H. Gerth. New York: Free Press.

Wood, Allen. 1984. "Kant's Compatibilism." In Self and Nature in Kant's Philosophy, edited by Allen W. Wood, 73-101. Ithaca: Cornell University Press.

Xu, Fuguan 徐復觀. 1969. Zhongguo renxinglun shi 中國人性論史 (A History of Chinese Theory on Human Nature). Taipei: Shangwu yinshuguan.

Yang Xiangkui 楊向奎, ed. 1985. Qingru xue'an xinbian 清儒學案新編 (New Compilation of Qing-Dynasty Confucian Scholars). Jinan: Qi Lu shushe.

$\mathrm{Yu}$, Ying-shih 余英時. 1989. Zhongguo sixiang chuantong de xiandai quanshi 中 國思想傳統的現代詮釋 (Modern Interpretation of Chinese Intellectual Tradition). Nanjing: Jiangsu renmin chubanshe. 